\section{Time (min)}

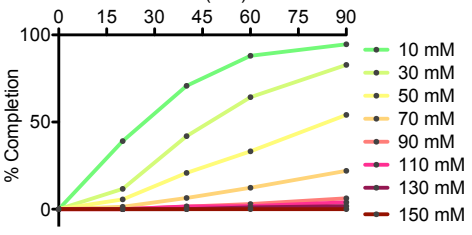

Time (min)

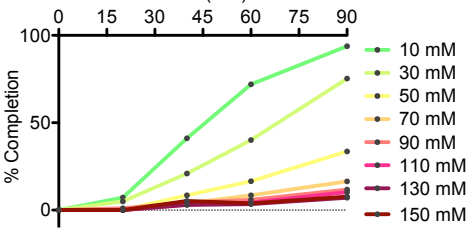

Time (min)

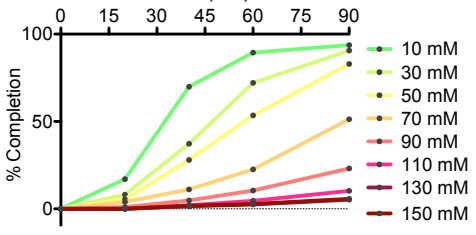

D

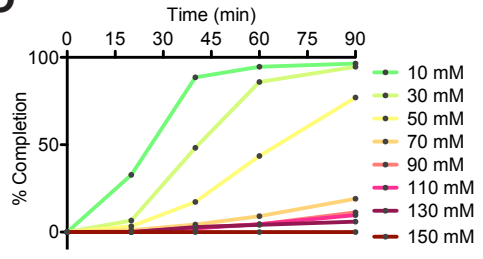

